\title{
SPATIAL CHANGES OF LAND USE PATTERN IN GUZELBAHCE DISTRICT (IZMIR)
}

\author{
N. S. Partigöç ${ }^{1, *}$, Ç. Tarhan ${ }^{2}$ \\ ${ }^{1}$ Department of City and Regional Planning, Pamukkale University, 20160 Kınıklı Denizli, Turkey - npartigoc@pau.edu.tr \\ ${ }^{2}$ Department of Management Information Systems, Dokuz Eylul University, 35160 Dokuzcesmeler Izmir, Turkey - \\ cigdem.tarhan@deu.edu.tr
}

KEY WORDS: Land use pattern, Urban settlements, Urban spatial organization, Geographical Information Systems, Izmir city.

\begin{abstract}
:
The primary issues related the spatial organization of urban settlements are based on the development of density and land use decisions leading due to the market mechanisms. The current spatial land use pattern of cities have emerged depending various factors such as the migration movements increased rapidly from the 1950s, the rapid and uncontrolled urbanization, the pressures of rent directing the market mechanisms, etc. This urbanization process also has accompanied many problems as the insecure construction for disasters, dense and solid urban texture, various weaknesses or deficiencies of urban infrastructure. As a consequence of the evaluation for social facility areas (gaps in urban area, open and green areas, etc.) as "potential investment areas", the loss of solid - void ratio and dense built-environment have been experienced in urban centres and also urban development directions. The main aim of this study is to examine the spatial effects of land use decisions between the years of 2002 -2017 under the influence of the Law 6360 in terms of urban planning discipline. These spatial variations related land use pattern are determined using Google Earth and Geographical Information Systems (GIS). According to the results, it is clearly understood that current land use patterns in Guzelbahce district have changed significantly in 15-years period. The results of analyses related the case area which the urban sprawl has seen are discussed and a variety of policies have been developed.
\end{abstract}

\section{INTRODUCTION}

In parallel with the developments in the World, it is clearly understood that it cannot be possible to deal with a single-level management system in Turkey because of two problems. The first one is that the administrative framework causes the new administrative problems and the second one is that the problems such as the effects of the urban duality on the social structure become more evident. This may be seen as the main reason as a starting point of new management models researched and discussed from the early periods of 1970s, both in the world that can replace the existing management systems in Turkey's agenda.

Until the 1980s, different suggestions have been developed for the cities which have "metropolitan areas" status in Turkey such as the establishment of municipal associations, democratic municipalities, producer-consumer regulated municipalities, municipalities based on cooperation and solidarity, resourcegenerating municipalities etc. However, these suggestions could not find a chance to be realized (Göymen, 1990; Gökaçt1, 1996). In the 1980s, the globalization discourse was on the agenda. There had been significant changes in spatial and administrative organizations. The local governments strengthened and also the provincial governor was at the forefront. "The Law on Administration of Metropolitan Municipalities", numbered 3030, issued in 1984, is a legal regulation that provides broad privileges to the metropolitan municipalities and sets forth the concept of "autonomous local government". In other words, this law is the first stage of comprehensive reforms related the management of large cities (Çelikyay, 2014; Dik, 2014).

After the enactment of this law, Turkey's first metropolitan municipalities have been founded in Istanbul, Izmir and
Ankara. So the efforts of many cities have accelerated in terms of earning the "metropolitan area" status. Additionally, the way of establishing and increasing the numbers of metropolitan cities have been opened with the Decree Law No. 504 issued in 1993. In the 2000s, the total numbers of metropolitan cities have increased to 16 including Adana, Bursa, Konya, Antalya, Diyarbakir, Eskişehir and Erzurum (Ürkmez and Çelik, 2016).

The second major reform on the management of the metropolitan cities is the "Metropolitan Municipality Law" numbered 5216 issued in 2004. This reform has become a current issue in a process that the effectiveness of local governments has increased and the changes in the globalization process in various geographies of the world are kept up to date. Both the scale and population criteria have been introduced to the borders of Metropolitan Municipality, by entering into force of this law. At the same time, Law No. 3030 has been abolished from the enforcement. A new system has been tried to be introduced for metropolitan cities that may expand their service areas of local governments. This law known also as "Compass Law" is based on the principle of border extension. Moreover, it is mandatory that the population of the settlements which locate $\max 1 \mathrm{~km}$ away from the surrounding area must be 750,000 people in order to establish a metropolitan city.

There are some city-wide differences in the expansion of settlements' boundaries. While the metropolitan borders (property limits) in the cities of Istanbul (province population $13.154,740$ people by 2012$)$ and Kocaeli $(1.634,691$ people by 2012); all the settlements with a maximum diameter of $50 \mathrm{~km}$ in the cities of Ankara (4.965,542 people in 2012) and Izmir $(4.005,459$ people in 2012) have been regulated so as to remain in the power and responsibility of the metropolitan municipalities. In Adana and Bursa, the responsibilities of the

\footnotetext{
* Corresponding author
} 
metropolitan municipalities are extended to a maximum of 30 $\mathrm{km}$ in diameter and also the area of responsibility of the metropolitan municipalities has been expanded to a maximum of $20 \mathrm{~km}$ in the cities of Eskişehir, Gaziantep, Kayseri, Sakarya, Diyarbakır, Konya, Mersin, Antalya, Erzurum and Samsun.

The latest reforms for local governments are the Law No. 5747 known as "Law on the Establishment of the District within the Borders of the Metropolitan Municipality and Amendments in Some Laws" and Law No. 6360 issued in 2012 called "Law on the Establishment of Metropolitan Municipality and TwentySeven Provinces in Fourteen Provinces and Amendments to Certain Laws and Decrees in the Law". In addition to these laws, first-stage municipalities and municipalities below 2000 persons have been closed with the enactment of Law No. 5747.

The "metropolitan model" is applied under the scope of this law, known as the "Metropolitan Law", numbered as 6360, has been put forward as a new management model. The number of metropolitan municipalities has been increased to 30 throughout the country. The existence of the special provincial administrations in the provinces of the metropolitan government has been terminated. Approximately 18,000 towns and villages have been removed from the legal entity. The villages have taken to the "neighbourhood" status. New districts and municipalities have been established. Investment Monitoring and Coordination Presidencies have been established in the metropolitan cities. Finally, it has become the municipal boundary of provincial borders in all metropolitan cities. Figure 1 shows the spatial distribution of major cities before and after the Law 6360. Table 1 lists the number of municipalities that changed before and after the Law numbered 6360 .

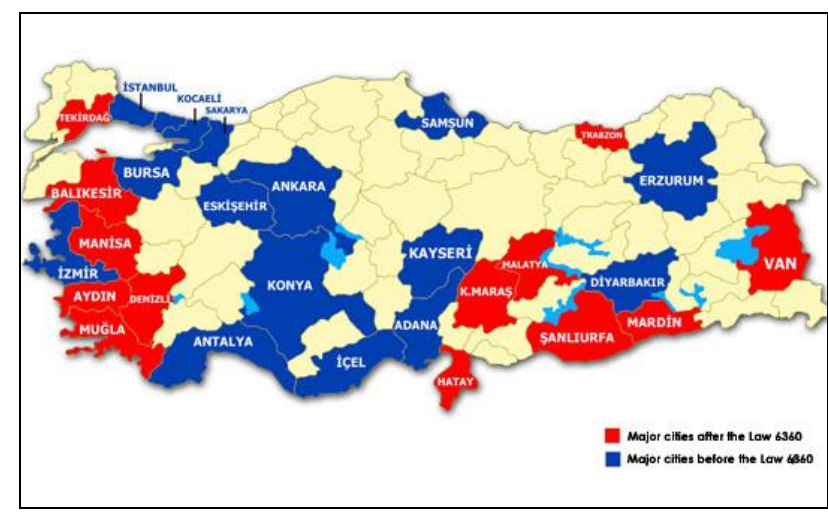

Figure 1. Major cities in Turkey before and after the Law 6360

\begin{tabular}{|l|c|c|}
\hline Municipalities & $\begin{array}{c}\text { The number of } \\
\text { municipalities } \\
\text { before the Law } \\
6360\end{array}$ & $\begin{array}{c}\text { The number of } \\
\text { municipalities } \\
\text { after the Law } \\
6360\end{array}$ \\
\hline Metropolitan municipality & 16 & 30 \\
District municipality & 143 & 501 \\
Town municipality & 1977 & 395 \\
Village administration & 34283 & 17720 \\
\hline
\end{tabular}

Table 1 . The number of municipalities in Turkey before and after the Law 6360
The purpose of the study is to examine the spatial effects of land use decisions which are developed for agricultural areas and protected areas due to their natural features until the Law 6360 issued by the year 2012 and also to evaluate the spatial and temporal changes occurred between the years $2002-2017$ in terms of urban planning discipline. The selected study area is the central area of Guzelbahce district among 11 centralized districts in Izmir metropolitan city including 12 settlements which three ones are disincorporated and their statuses are changed as "neighbourhood". Besides this district has already contain fertile agricultural areas, vineyards and also forests, significant spatial changes based on housing demand have been observed as a result of its location in the urban development axes of Izmir city.

\section{THE POSSIBLE EFFECTS OF LAW NO. 6360 ON URBAN PLANNING}

The amendments to Law No. 6360 are very important in terms of spatial planning processes, both institutional and administrative, when our country is currently considering the limited experience of effectively managing metropolitan areas. When these changes are investigated, it is clearly observed that the urbanization rate in Turkey has increased critically from $77 \%$ to $91 \%$. Between the years 2012 and 2013, about 10 million rural people have decreased and about 11 million urban populations have increased (İrdem and Mutlu, 2016). The population density in the country is 100 people $/ \mathrm{km}^{2}$. The 12 cities (Şanlıurfa, Mardin, Balıkesir, Denizli, Kayseri, Kahramanmaraş, Muğla, Malatya, Eskișehir, Van, Konya and Erzurum) have taken to the "neighbourhood" status stood below the country average in terms of the population density.

As one of the amendments to this law, the removal of the legal entity of towns and villages caused the evaluation of all the settlement units in terms of the qualitative and quantitative maintenance as "city". Therefore, the concept of "providing better quality service with fewer resources" has left a legitimate concern about the provision of services to settlements. These services are under the authority and responsibility of the local governments based on the scale economy of the metropolitan municipalities (İrdem and Mutlu, 2016). It poses serious problems related accessing of citizens the existing services who settle in scattered settlements and participation in the decisions of the local councils.

The preservation of structural and characteristic features of settlements has brought with different professions by the enactment of Law No. 6360 such as idiosyncratic elements, rural identity, original architectural texture, etc. From this point, it has been an issue that the city and municipalities in each metropolitan municipality, which are planned to be constructed within the borders of the metropolitan municipalities, are considered as "potential urban areas" and "project areas" in the development plans for rural settlements located near urban centres or in urban development directions. As a natural consequence of this process, people settled in villages have been losing their rights over their own way of life.

The possible socio-cultural outcomes that legal arrangements may create at the level of settlements are one of the factors shaping the spatial organization within the framework of urban planning discipline. "Urbanization/urbanism awareness" is one of the main problems for the people living in rural settlements that have been converted into neighbourhoods and articulated in 
the city. Actually, it should be perceived as a process of socialization rather than being perceived as a legal process.

The planning process in large scale which is developed plan decisions except sub-scale plans and partial plans is one of the possible consequences of the Law 6360 based on the planning principles and practices. With the enactment of this law, the production of large-scaled plan decisions for all settlements in a metropolitan city has created an approach. This approach actually is not co-ordinated with the sub-scaled plans, is disconnected from the whole plan and also does not observe the local dynamics. At the end of the non-integrative planning processes, any significant spatial and societal changes will be observed in the middle and long term because of being governed by a single authority. Moreover, any settlements will have to face the irreversible planning decisions.

\section{DATA AND THE STUDY AREA}

Izmir city is a coastal city where the modern urbanization steps have been taken at the present time, the rapid urbanization process has been observed after the 1950s, the spatial development mechanisms have been significantly affected by the national political and economic crisis, any urban changes referred a shifting from a small coastal town to a metropolitan area, the topographic thresholds are shaping the urban spatial development. Actually this city has been significantly known in the national and international platforms depending of various factors such as international fairs and congresses, maritime commercial facilities, the cultural and natural heritage, historical process, etc (Izmir Metropolitan Municipality, 2009).

The process of urban development has been proceeded in parallel to the population increase and also technological innovations in this metropolitan city due to adopting partitive planning approaches. Moreover, Izmir city cannot be developed in a planned and controlled way because of the preference of local practices brought economic benefits in a short term, the inadequacy of meeting the increasing housing and urban facilities' demand, the realization of local urban renewal projects, the rapid migration in recent times (Yapkuöz, 2018).

The selected study area named as Guzelbahce district and located in the west part of the entire city is one of central districts of Izmir metropolitan city. This area is a "metropolitan district" that has approximately 32.000 people and also the urbanization rate is $94.5 \%$. The spatial development can be easily observed throughout the main arterial road lying north south direction. According to the current land use pattern of the study area, there exist various usages such as low density and secondary residential areas, fertile agricultural areas, forests, stream beds, citrus and olive trees, vineyards and greenhouses, ports, educational and health facilities, market places, open and green areas, etc. This district is actually attractive to settle and plan step by step. The principal reasons of this attractiveness can be listed as its critical location throughout the main arterial routes, strong relationships with the coastal area, being easily accessible to the city centre, various transportation modes, more qualified and liveable urban environment comparison to Izmir city (Izmir Metropolitan Municipality, 2009; Izmir Chamber of Commerce, 2018; Guzelbahce Municipality, 2018).

The location of district in the west part of metropolitan city has critically affected the physical development processes. In comparison to previous periods, the rate of immigration has decreased significantly. Less slum areas as a threatening factor of planned development is not only one of positive aspects related the study area but also an important effect to rise the preferability of district. Figure 2 shows the relation between built and natural environment and current urban land pattern in the study area. Also, Figure 3 represents the location of the study area and Izmir city. Table 3 shows the status changes of settlements in the study area by the Law 6360, while Table 4 represents the populations of neighbourhoods in the study area by the year 2017. Therefore, Table 5 shows the populations of new neighbourhoods before and after the Law No.6360 and Figure 4 shows the population distribution of neighbourhoods in the study area between the years $2007-2017$.

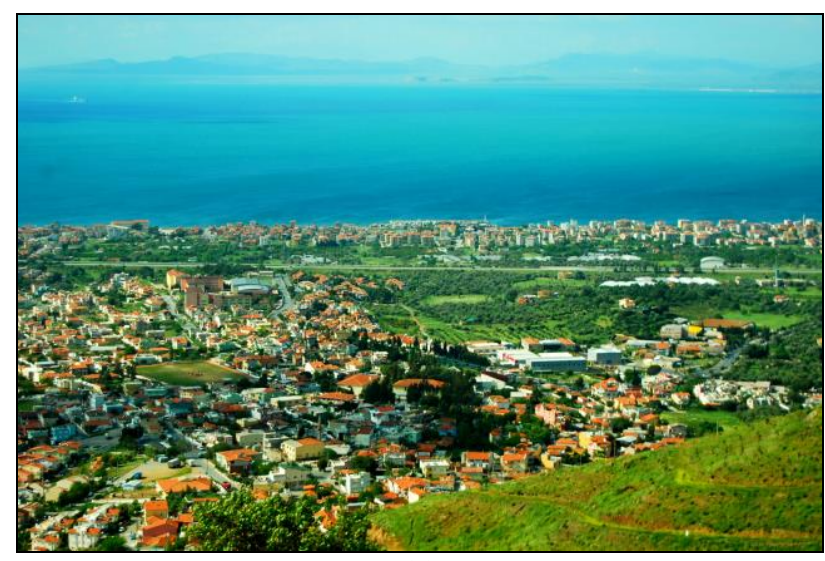

(a)

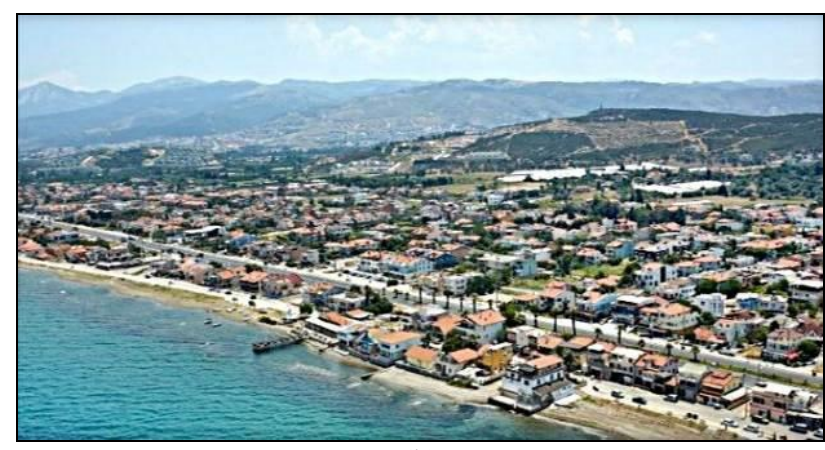

(b)

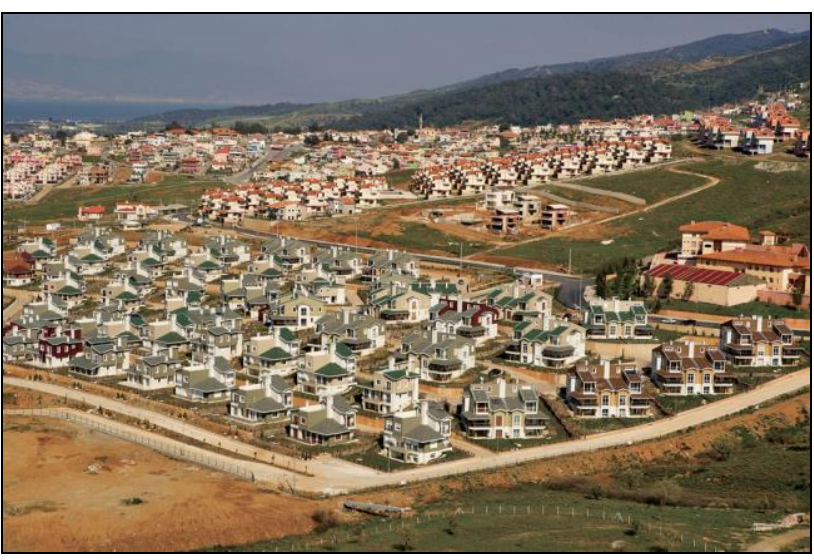

(c)

Figure 2. The relation between built and natural environment and current urban land pattern in the study area 


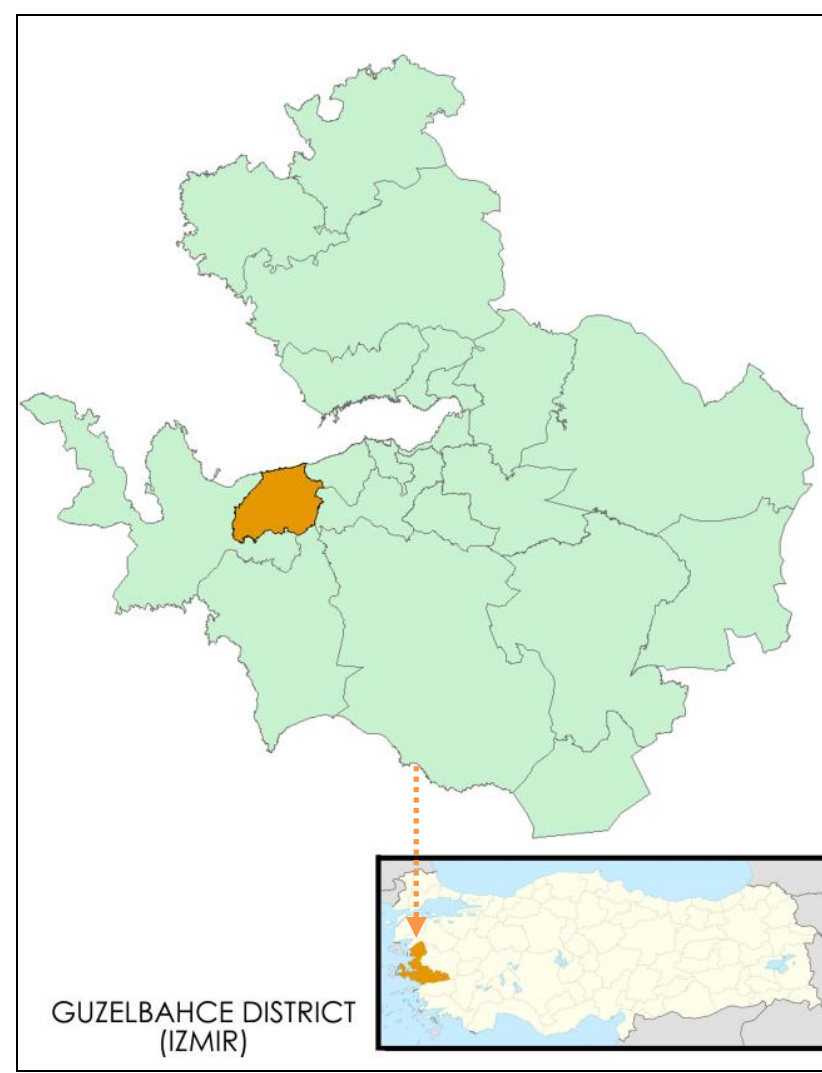

Figure 3. The location of Izmir metropolitan city and study area

\begin{tabular}{|c|c|c|}
\hline $\begin{array}{c}\text { Neighbourhoods } \\
\text { after the Law 6360 }\end{array}$ & $\begin{array}{c}\text { Previous status } \\
\text { of settlements }\end{array}$ & $\begin{array}{c}\text { Any status changes } \\
\text { of settlements }\end{array}$ \\
\hline Ataturk & Neighbourhood & $\mathrm{x}$ \\
\hline Camli & Village & $\sqrt{ }$ \\
\hline Celebi & Neighbourhood & $\mathrm{x}$ \\
\hline Kahramandere & Neighbourhood & $\mathrm{x}$ \\
\hline Kucukkaya & Village & $\sqrt{ }$ \\
\hline Maltepe & Neighbourhood & $\mathrm{x}$ \\
\hline Mustafa Kemal Pasa & Neighbourhood & $\mathrm{x}$ \\
\hline Payaml1 & Village & $\sqrt{ }$ \\
\hline Siteler & Neighbourhood & $\mathrm{x}$ \\
\hline Yaka & Neighbourhood & $\mathrm{x}$ \\
\hline Yal1 & Neighbourhood & $\mathrm{x}$ \\
\hline Yelki & Neighbourhood & $\mathrm{x}$ \\
\hline
\end{tabular}

Table 3. The status changes of settlements by the Law 6360

\begin{tabular}{|c|c|}
\hline Neighbourhoods of Guzelbahce district & Population \\
\hline Ataturk & 2772 \\
\hline Camli & 1452 \\
\hline Celebi & 2502 \\
\hline Kahramandere & 4732 \\
\hline Kucukkaya & 171 \\
\hline Maltepe & 3705 \\
\hline Mustafa Kemal Pasa & 2563 \\
\hline Payamli & 294 \\
\hline Siteler & 2611 \\
\hline Yaka & 525 \\
\hline Yali & 6144 \\
\hline Yelki & 3958 \\
\hline
\end{tabular}

Table 4. The populations of neighbourhoods in Guzelbahce district by the year 2017 (Önen, 2015)

\begin{tabular}{|c|c|c|}
\hline $\begin{array}{c}\text { New Neighbourhoods after } \\
\text { the Law No.6360 }\end{array}$ & $\begin{array}{c}\text { Population } \\
\text { before 2012 }\end{array}$ & $\begin{array}{c}\text { Population } \\
\text { after 2012 }\end{array}$ \\
\hline Camli & 605 & 1452 \\
\hline Kucukkaya & 127 & 171 \\
\hline Payaml1 & 330 & 294 \\
\hline
\end{tabular}

Table 5. The populations of new neighbourhoods before and after the Law No.6360 (Önen, 2015; TSI, 2017)

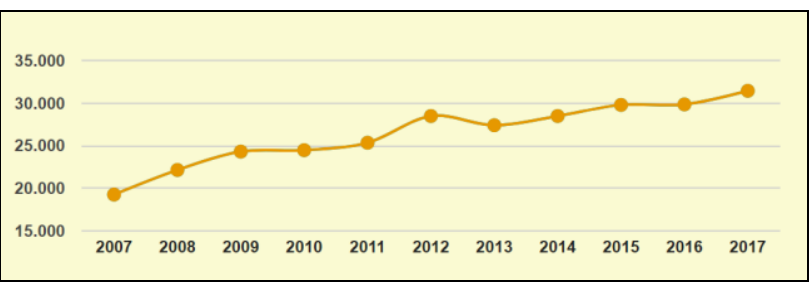

Figure 4. The population distribution of neighbourhoods in the study area between the years 2007 - 2017

According to the results of doctoral thesis completed and published by a landscape architect from Ege University (Izmir) called Erhan Önen, the land usages in current urban pattern of Guzelbahce district are determined and classified using spatial analyses. The total area of Guzelbahce district is approximately $172.000 \mathrm{~m}^{2}$ (17 ha.). The size of urban areas with open and green areas is $23.908 \mathrm{~m}^{2}(13.9 \%)$, the size of fertile agricultural areas with citrus and olive trees, vineyards and greenhouses is $27.692 \mathrm{~m}^{2}(16.1 \%)$, the size of forests is $119.970 \mathrm{~m}^{2}(69.75 \%)$ and also the size of stream beds is $430 \mathrm{~m}^{2}(0.25 \%)$ in the district (Önen, 2015).

In Figure 5, the comparative satellite images with changing urban pattern in the district between the years $2002-2017$ are represented. (a) shows the satellite image for the year 2002, (b) shows the satellite image for the year 2005, (c) shows the satellite image for the year 2008, (d) shows the satellite image for the year 2011, (e) shows the satellite image for the year 2014 and (f) shows the satellite image for the year 2017. In Figure 6, the spatial changes in urban pattern in the district between the years $2002-2017$ and also the defined areas throughout development axes of the district are represented.

In the study area, there exist three settlements which have been disincorporated and their statuses are changed as "neighbourhood" by the Law No. 6360 (Table 3). These new settlements are Kucukkaya, Payamli and Camli neighbourhoods. By the year 2012, the total number of neighbourhoods located in the study area is 12 . The neighbourhoods that their statuses have been changed by the law locate far away from the district centre, the coastline and also the main arterials named Izmir-Seferihisar Road and IzmirCesme Highway (Figure 6). 


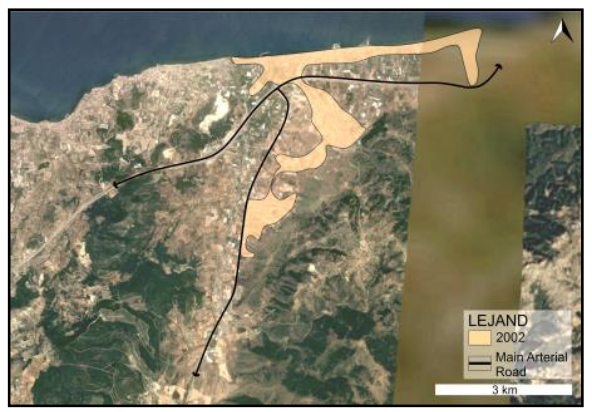

(a)

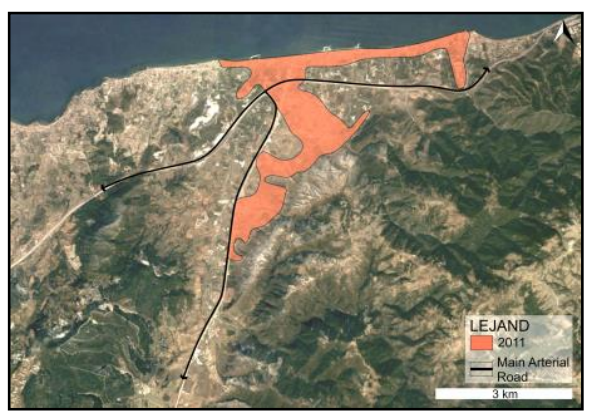

(d)

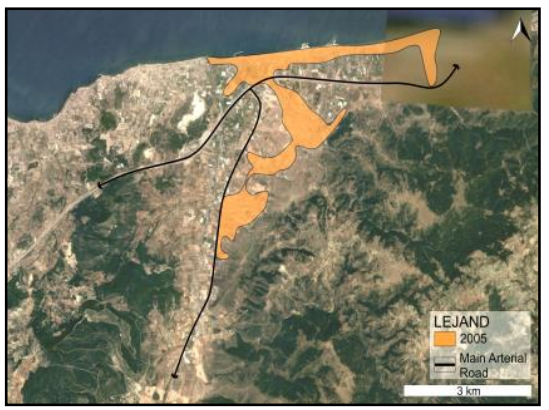

(b)

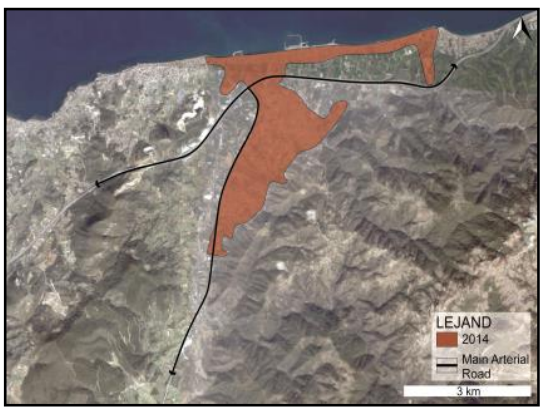

(e)

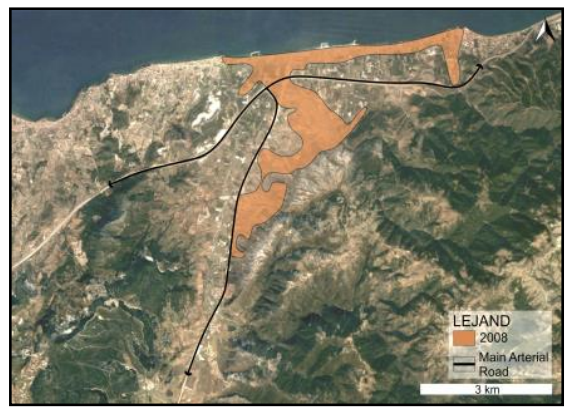

(c)

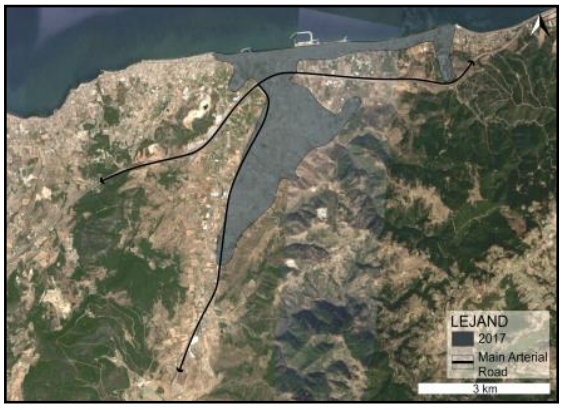

(f)

Figure 5. The comparative satellite images with changing urban pattern in the district between the years $2002-2017$

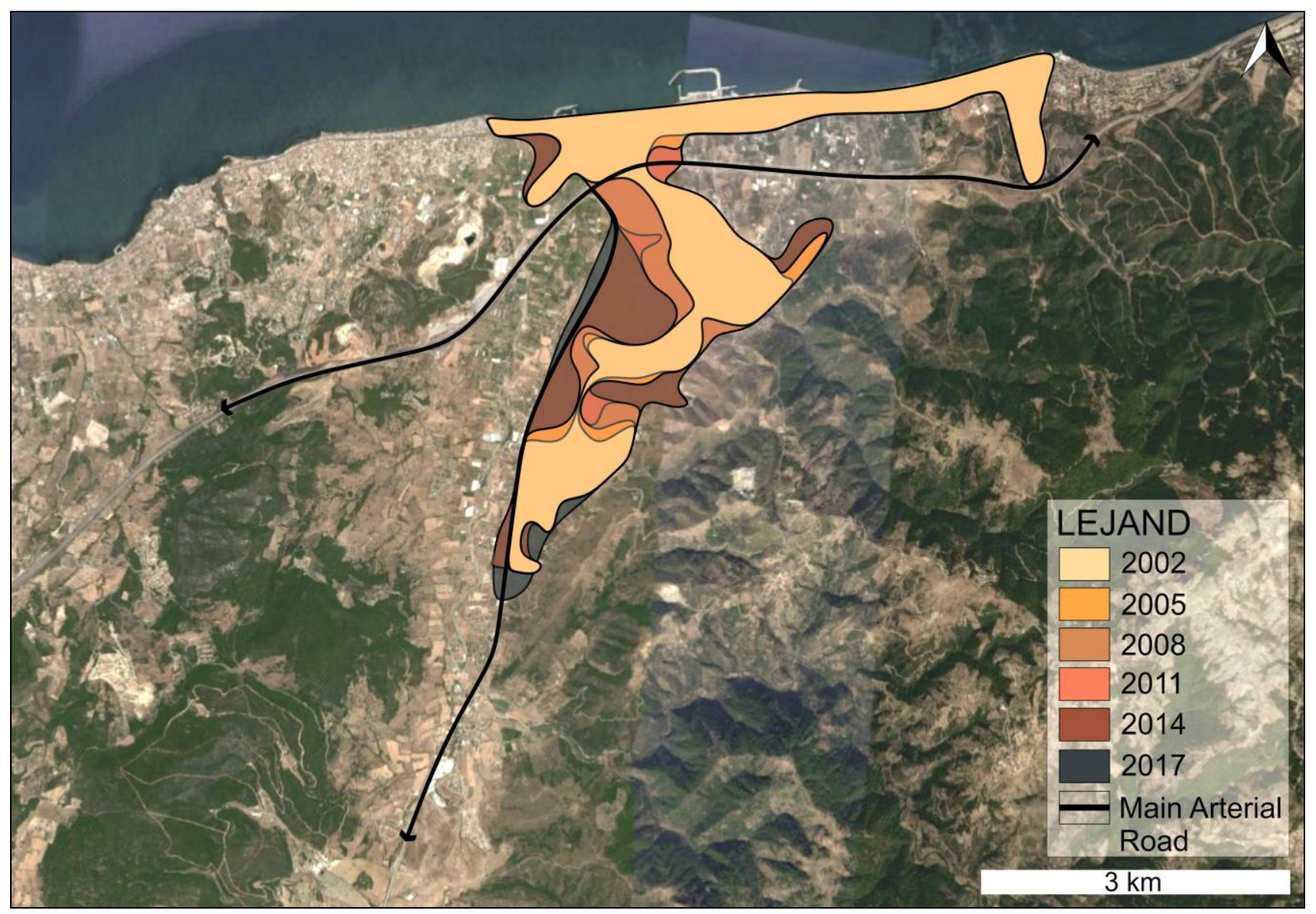

Figure 6. The spatial changes in urban pattern between the years $2002-2017$ and the areas throughout development axes in district 
As a result of examining the spatial variation in land use pattern comparatively in the study area using the satellite images between the years $20002-2017$ via Google Earth software, it is determined that the observed spatial changes and development trends have been affected critically in the decennium (the 10years period) and significant land losses especially in natural environment in the study area as well.

The current land usages have been mostly observed along the coastline and in the east part of main arterial named IzmirSeferihisar Road as low density secondary residential areas in 2002. In the same period, any physical union between the traditional rural pattern located in the south part of Izmir-Cesme Highway and the new urban pattern located in the east part of Izmir-Seferihisar Road. This union has been occurred in empty and open areas in the study area (Figure 5a). In 2005, it has been determined that new urban facilities in Yelki neighbourhood and also current urban land usages in Yaka neighbourhood have concentrated (Figure 5b).

In 2008, low density residential areas and closed sites located around the coastline and in the east part of Izmır-Seferihisar Road have increased significantly. In addition to this, it is observed that the pattern of residential usages has concentrated around two main arterial roads especially in Kahramandere neighbourhood (Figure 5c). In 2011, it is clearly determined that losses of natural qualified areas and also the rate of urbanization have increased importantly. This period includes the variation of current land use pattern due to new developments, the depredation of fertile agricultural areas and natural qualified areas (vineyards, citrus and olive trees, etc.) in a rapid and uncontrolled way. In other words, the year 2011 is a significant breaking point for Guzelbahce district in terms of the land use pattern changes (Figure 5d).

In terms of the spatial changes in 2014 , it has been observed that losses of natural and non-built areas have increased critically. Therefore, almost all of the area located in the east part of Izmir-Seferihisar Road has been opened to build and current rural pattern in the coastline has turned into the urban pattern. According to the spatial analyses, a process for "identity change" has been determined especially in Yelki, Yaka and Maltepe neighbourhoods (Figure 5e).

In 2017, significant variations in a negative way related the current rural land use pattern observed 15 years ago, the spatial and proportional distribution of land use types, the balance between conservation and utilization have been determined. While the spatial changes can be observed clearly in certain neighbourhoods (Yelki, Kahramandere, Maltepe, Yaka, etc.) located near the coastline and main arterials, on the other hand, there has been no significant spatial changes in certain neighbourhoods (Kucukkaya, Payamli, Camli, etc.) located far away from the district centre, arterials, etc (Figure 5f).

\section{RESULTS AND DISCUSSION}

It is vitally significant to monitor the changes in spatial organisation of various urban areas and to compare previous and following periods of the Law No.6360 in terms of losses, advantages, etc. In this study, the main aim is to analyse the spatial effects of land use patterns that vary within the urban planning process under the effect of the Law 6360 issued by the year 2012. Moreover, the determination of spatial variation occurred between the years of $2002-2017$ in terms of urban planning discipline. For the selected study area as Guzelbahce district including 12 settlements which three ones are disincorporated and their statuses are changed as "neighbourhood", the results of this study are crucial. Because, these have revealed that the decisions of local governments are so decisive and directive in terms of leading the development dynamics and trends of urban areas. In addition, the consequences of this study are established using satellite images of different years between $2002-2017$, urban qualified areas have become more dominant over the rural areas (especially agricultural areas) by the time and new investments (Figure 6).

In 15 years period between the years $2002-2017$, it is certainly observed that the current land use pattern and types have been significantly changed in Guzelbahce district. There exist triggering reasons to occur these changes as new investments' decisions, development routes of Izmir city, inadequate supply for housing and urban facilities, increasing demand for secondary housing out of city centre, etc. The spatial variation has been observed more clearly in in certain neighbourhoods located near the coastline and main arterials, while the partial and local changes can be seen in certain neighbourhoods located far away from the district centre, main arterials (Figure $6)$.

As a result of the amendments to the Law 6360 , it is clearly understood that Guzelbahce district as a metropolitan district will have to face new challenges such as the sustainability of rural qualified areas, the bringing local dynamics into prominence, etc. These problems will become increasingly visible with economic, social and spatial dimensions to the local governments which have authorities and responsibility of settlements and also citizens which settle in dense urban areas with increasing housing demand.

For the decision makers, the various changes in urban areas must be taken into consideration in a lot of ways after the statutes at large such as the Law No. 6360. These changes can be listed as expanding the local governments' authorities, ensuring adequate technical infrastructure to citizens in a controlled and equal way, supervising the urbanization process, discussing the possible results of rural - urban dilemma, etc. In this process, certain phenomenon must be prioritized like as localization, democratization, decentralization, the development of integrated urban models by the authorities. 


\section{REFERENCES}

Çelikyay, H., 2014. Değişen Kent Yönetimi ve 6360 Say1l Büyükşehir Yasası. Journal of SETA, pp.101.

Dik, E., 2014. 6360 Sayılı Kanun Bağlamında Köylerin Mahalleye Çevrilmesi Sorunu, Mülkiye Dergisi, 38(1), pp. 75 102 .

Ercan, E.M., 2017. Kentlerimizin İçinde Bulunduğu Planlama ve Yönetim Sorunları. Planlama Dergisi, 2007/2.

Ersoy, M., 2013. 6360 Sayılı Yasa ve Mekânsal Planlama Sorunları. GAP Belediyeler Birliği Dergisi, Mayıs, Haziran Temmuz sayıs1, pp. 20-32.

Google Earth, 2018. Satellite images between the years 20022017.

Gökaçtı, M.A., 1996. Dünyada ve Türkiye'de Belediyecilik. Ozan Yayıncılık, İstanbul.

Görmüş, S., Cengiz, S, 2016. Denizli'de Kentsel Büyümeyi Yönlendiren Değişkenlerin Analizi, 6. Uzaktan Algılama-CBS Sempozyumu (UZAL-CBS2016), Adana.

Göymen, K., 1990. Türk Belediyeciliğinde Ankara Örneği: 1973-1980. Türk Belediyeciliğinde 60. Y11, Uluslararası Sempozyum, Ankara, 23-24 Kasim 1990, Bildiriler ve Tartışmalar, Ankara Büyükşehir Belediyesi Yayınları, Ankara, pp. 395-404.

Guzelbahce Municipality, 2018. Official web site, http://guzelbahce.bel.tr/.

İrdem, İ., Mutlu, A., 2016. 6360 Sayılı Yasayla "Kır-Kent" Kavramlarının Muğlâklaşması Sorunu ve Olası Sonuçları. KAYSEM 10, İzmir, pp. 159-176.

Izmir Chamber of Commerce, 2018. The Report of Guzelbahce District. Official web site, http://www.izto.org.tr/tr/.

Izmir Metropolitan Municipality, 2009. Izmir Kentsel Bölge Nazım İmar Planı Raporu, Izmir.

Önen, E., 2015. Kentsel açık-yeşil alan stratejilerinin belirlenmesi: Güzelbahçe (İzmir) ilçesi örneği. PhD Thesis, Ege University, Izmir.

Partigöç, N.S., 2018. Kentleşme Sürecinde Kırsal Alanların Mekansal Değişimi ve Dönüşümü: Denizli Kenti Örneği (The Spatial Variation of Rural Settlements in the Urbanization Process: The Case of Denizli City), Bilişim Teknolojileri Dergisi, 11 (1), pp. $89-98$.

Turkish Statistical Institute, 2017. Population of neighbourhoods in Guzelbahce district.

Ürkmez, G.K., Çelik, H.Z., 2016. 6360 Sayılı Yasayla Mekansal İlişki Sisteminin Kır-Kent İkileminde Yeniden Yapılanışı ve Yerel Yönetimler: Kayseri İli Örneği. Çağdaş Yerel Yönetimler, 25 (3), pp. 69-94.

Yapkuöz, F., 2018. Geçmişten bugüne İzmir Şehir Planı. http://www.izmirdergisi.com/tr/soylesi/2159-gecmistenbugune-izmir-sehir-plani. 